(c) American Dairy Science Association, 2004.

\title{
Growth Performance and Health of Dairy Calves Bedded with Different Types of Materials
}

\author{
R. Panivivat, ${ }^{1}$ E. B. Kegley, ${ }^{1}$ J. A. Pennington, ${ }^{2}$ \\ D. W. Kellogg, ${ }^{1}$ and S. L. Krumpelman ${ }^{1}$ \\ ${ }^{1}$ Department of Animal Science, \\ University of Arkansas, Fayetteville 72701 \\ ${ }^{2}$ Department of Animal Science, \\ University of Arkansas Cooperative Extension Service, \\ Little Rock 72203
}

\begin{abstract}
Granite fines, sand, rice hulls, long wheat straw, and wood shavings were compared as bedding for 60 female dairy calves. Growth, health, stress indices, and behavior of newly born calves, along with physical characteristics and bacterial counts of bedding, were evaluated for $42 \mathrm{~d}$ during August to October, 2002. Overall average daily gain and dry matter intake of calves did not differ due to bedding type, although during wk 2 calves housed on rice hulls had the greatest dry matter intake and those housed on wood shavings had the lowest. During wk 2, calves housed on granite fines and sand were treated more often for scours, and calves housed on long wheat straw received the fewest antibiotic treatments (week by bedding material interaction). Granite fines formed a harder surface than other bedding, and calves housed on granite fines scored the dirtiest. When bedding materials were evaluated, sand was scored to be the dirtiest, while pens bedded with rice hulls, long wheat straw, and wood shavings scored cleaner. Long wheat straw had the warmest surface temperature, and rice hulls and wood shavings were warmer than granite fines and sand. Serum cortisol, $\alpha_{1}$-acid glycoprotein, immunoglobulin $\mathrm{G}$ concentrations, and the neutrophil:lymphocyte ratio were not affected by bedding type. On $d 0$, coliform counts were greatest in rice hulls. After use, coliform counts were greatest in long wheat straw (week by bedding material interaction). On $\mathrm{d} 42$, the concentration of ammonia at $10 \mathrm{~cm}$ above the bedding was lowest for long wheat straw. Growth performance of calves bedded for $42 \mathrm{~d}$ with 5 bedding types did not differ; however, the number of antibiotic treatments given for scours was greatest on granite fines and sand; coliform counts in the bedding were highest in rice
\end{abstract}

Received March 4, 2004.

Accepted July 23, 2004.

Corresponding author: E. B. Kegley; e-mail: ekegley@uark.edu. hulls before use and in long wheat straw after $42 \mathrm{~d}$ of use.

(Key words: calf bedding material, growth performance, health, bacterial count)

Abbreviation key: AGP $=\alpha_{1}$-acid glycoprotein; $\mathbf{N}: \mathbf{L}=$ neutrophil:lymphocyte ratio.

\section{INTRODUCTION}

The early preweaning stage of a calf's life is critical. Housing and environmental factors, including bedding material, are important. The use of bedding material for calves can provide comfort, decrease the risk of contracting disease, and reduce stress. Norheim and Simensen (1985) reported that calves kept on elevated, perforated floors had higher IgG than calves kept on a solid floor without bedding. However, when calves were older than $30 \mathrm{~d}$, concentrations of IgG were greatest when calves were kept on the solid floor with use of some bedding.

Hunter and Houpt (1989) studied bedding preference in ponies and concluded that they preferred areas of pens bedded with wood shavings rather than bare concrete. Lactating cows preferred to use free-stalls bedded with sand or sawdust compared with mattresses (Tucker et al., 2003). However, temperature and humidity may affect the animal's behavior, quality of bedding materials, and bacteria in the bedding types (Hogan et al., 1989; Bey et al., 2002). In summer, pigs prefer to lie on concrete floors, but in winter they prefer to lie on straw bedding (Fraser, 1985). Lactating cows preferred free-stalls bedded with sand as compared with mattresses in summer; however, cows used stalls bedded with mattresses and sawdust in the winter (Thoreson et al., 2000). Long wheat straw has been used traditionally for calf bedding, but it is expensive or unavailable in many areas. Other reasonably priced materials available in Central Arkansas are granite fines, rice hulls, and wood shavings. 
In spite of the importance of bedding material type to keep calves clean, dry, comfortable, and healthy, there is limited information concerning how bedding material type affects calf growth performance and health. The objectives of this study were to determine the effects of 5 types of bedding material on growth, physiological stress, and behavior of calves and to monitor costs and physical characteristics of the material used.

\section{MATERIALS AND METHODS}

\section{Animals, Bedding Materials, and Design}

Dairy calves in the study were born at the Ark-Tenn Dairy Research and Development Facility near Center Ridge, AR. About 150 female calves were housed in a barn that was $18.3 \mathrm{~m}$ wide and $68.6 \mathrm{~m}$ long with open sides that were $4.3 \mathrm{~m}$ high. Pens $(1.2 \times 1.8 \mathrm{~m})$ used during the trial were located in the middle of the calf barn. The trial was conducted from August to October 2002. Physical contact among calves was prevented by 0.6-m spaces between pens or by a wooden wall (1.1 $\mathrm{m}$ high) that separated adjoining pens. All pens had plastic buckets for feed and water attached outside the front of the pen. Dirt floors were covered with 2.5 $\mathrm{cm}$ (mean weight of $99 \mathrm{~kg}$ ) of ground limestone (grade 4). Limestone was covered with $5.1 \mathrm{~cm}$ of the different types of bedding material composing the 5 treatments. The 5 bedding types were river sand (Lentz Company, Morrilton, AR); granite fines, a by-product of crushing syenite granite rock (Donna Fill Granite Fines, Little Rock, AR); rice hulls (Brinkley Dryer, Brinkley, AR); long wheat straw; or soft wood shavings (Travis Lumber Co., Mansfield, AR). The long wheat straw was delivered baled, and the other materials were delivered loose in bulk. Costs of bedding material (retail price $/ 100 \mathrm{~kg}$ ) were $\$ 0.22$ for granite fines, $\$ 0.44$ for sand, $\$ 0.50$ for rice hulls, $\$ 10$ for long wheat straw, and $\$ 1.10$ for wood shavings. The densities $\left(\mathrm{kg} / \mathrm{m}^{3}\right)$ of the bedding materials were measured to be 1605 for granite fines, 1352 for sand, 92.9 for rice hulls, 69.7 for long wheat straw, and 139.4 for wood shavings. With the exception of wheat straw, these densities represent the weight of materials as they were shoveled into pens to a depth of $5.1 \mathrm{~cm}$. For pens bedded with wheat straw, the straw was torn from the bale in 5.1-cm thick sections, which were laid intact in the pen to cover the floor. These sections were then scattered, and the depth of this loose material exceeded $5.1 \mathrm{~cm}$ at the start of the study. Hardness was measured with a DICKEY-john Soil Compaction tester (DICKEY-john Corporation, Auburn, IL) at $3.2 \mathrm{~kg} / \mathrm{cm}^{2}$ of pressure with a $6.3-\mathrm{cm}$ diameter disk. Hardness was reported as the centimeters of penetration of the disk into the material; therefore, larger numbers indicate softer materials. Five sites within the pen (approximately $25 \mathrm{~cm}$ from each corner and a center point) were measured and averaged before placing the calf in the pen. On d 0, bedding samples were collected to measure DM and absorbency.

Within $6 \mathrm{~h}$ of birth, 60 (58 Holstein, 1 Brown Swiss $\times$ Holstein, and 1 Guernsey $\times$ Holstein) calves were weighed and vaccinated intranasally with $2 \mathrm{~mL}$ of a modified live bovine rhinotracheitis and parainfluenza $_{3}$ virus vaccine (TSV-2; Pfizer Animal Health, Exton, PA) and orally with $3 \mathrm{~mL}$ of a modified live bovine rotavirus and coronavirus vaccine (Calf-Guard; Pfizer Animal Health). Calves were injected intramuscularly with $1 \mathrm{~mL}$ of iron hydrogenated dextran (containing $100 \mathrm{mg}$ of Fe; VEDCO, Inc., St. Joseph, MO), $1 \mathrm{~mL}$ of vitamin A (500,000 IU) and D (75,000 IU; VEDCO, Inc.), and $6 \mathrm{~mL}$ of selenium and vitamin $\mathrm{E}(2.19 \mathrm{mg}$ sodium selenite $/ \mathrm{mL}$ [1 $\mathrm{mg}$ selenium $/ \mathrm{mL}]$ and $50 \mathrm{mg}$ [68 USP units] of vitamin E/mL; BO-SE; ScheringPlough Animal Health Corp., Union, NJ). Each calf was identified with an ear tag, and its navel cord was dipped with $10 \%$ tincture of iodine (VEDCO, Inc.). No colostrum from the dams was fed to calves. Calves were fed $350 \mathrm{~g}$ of a commercial colostrum supplement (Colostrum Plus Bovine IgG-Escherichia coli Antibody; Jorgensen Laboratories, Inc., Loveland, CO) one time only within $6 \mathrm{~h}$ of birth by plastic esophageal feeder. Calves were reweighed at $1 \mathrm{~d}$ of age to establish an average initial BW. At $1 \mathrm{~d}$ of age, calves were randomly assigned to individual pens on 1 of 5 types of bedding materials (12 calves per treatment). Calves began the study over a 4 -wk period ( 3 calves per treatment per week). The week that calves started was used as a block in the statistical models.

Calves were offered $2 \mathrm{~L}$ of medicated milk replacer (Vigortone Ag Products, Inc., Cedar Rapids, IA) mixed with Optimil concentrate calf supplement-MR type B medicated feed (Manna Pro Corp, St. Louis, MO) twice daily at 0700 and $1530 \mathrm{~h}$ with nipple bottles throughout this study. Medicated milk replacer was formulated to contain oxytetracycline at $220 \mathrm{mg}$ and neomycin sulfate at $440 \mathrm{mg} / \mathrm{kg}$ of milk replacer powder. Optimil concentrate was formulated to contain oxytetracycline- $\mathrm{HCl}$ at $7.04 \mathrm{~g}$ and neomycin at 14.08 $\mathrm{g} / \mathrm{kg}$ of Optimil powder. After $760 \mathrm{~g}$ of Optimil was mixed with $22.7 \mathrm{~kg}$ of the milk replacer, $227 \mathrm{~g}$ of this mixture was used the make the $2 \mathrm{~L}$ offered.

Commercial calf starter (Caldwell Milling Co; Rosebud, AR) was offered once daily in the morning in an open plastic bucket beginning on $\mathrm{d} 3$. Calves were offered $0.12 \mathrm{~kg} / \mathrm{d}$ of starter in wk $1,0.24 \mathrm{~kg} / \mathrm{d}$ in wk 2 , and were increased to ad libitum in wk 3 until the weaning date after wk 6 . Each morning any orts were 
removed, weighed, and discarded, and fresh starter was offered. Starter contained a coccidiostat $(49.5 \mathrm{mg} /$ $\mathrm{kg}$ as fed; Deccox; Alpharma Animal Health Division, Lowell, AR). Representative samples of feed were taken every $14 \mathrm{~d}$ for analysis. Commercial medicated milk replacer and calf starter were analyzed for DM (AOAC, 1990), CP (nitrogen by combustion; Elemental Analyzers for the determination of nitrogen; Elementar Americas, Inc., Mt. Laurel, NJ), and fat (AOAC 920.39C , 1990). Calf starter and milk replacer samples were digested in duplicate by wet ash methodology using concentrated trace metal grade nitric acid in 50$\mathrm{mL}$ conical, trace metal free, polypropylene centrifuge tubes with a heated digestion block (ModBlock, CPI International, Santa Rosa, CA). After digestion, samples were brought to $50 \mathrm{~mL}$ volume with a $0.1 \%$ cesium chloride solution. Concentrations of $\mathrm{Ca}$ were determined by atomic absorption spectroscopy (Perkin-Elmer, model 5000, Norwalk, CT). Concentrations of P were determined with a spectrophotometric procedure (AOAC, 1990) modified for use in microtiter plates. Starter and milk replacer intakes were recorded daily. Calf starter refusals were measured daily in the morning. Milk refusal was measured twice daily. Water was available at all times in an open plastic bucket. Calves were weighed initially and at $1,2,4$, and $6 \mathrm{wk}$ of age (an average of weights on 2 consecutive $d$ was used for the final BW).

Calves were housed until weaning at 6 wk without removing any bedding materials from the pens. However, at 2-wk intervals, a bedding score was determined for each pen, then bedding materials that had been forced out around the pen were removed and placed back into that pen before adding new bedding material, if required by bedding score. The bedding score was rated on a scale of 1 to 5 as follows: $1=$ dry and clean, $2=20$ to $40 \%$ of surface dirty or wet, $3=$ 40 to $60 \%$ of surface dirty or wet, $4=60$ to $80 \%$ surface dirty or wet, and $5=>80 \%$ of surface dirty or wet. Approximately $1.3 \mathrm{~cm}$ (depth) of additional bedding was added over the previous bedding when the bedding score was $>3$, or if less than $50 \%$ of bedding material remained in the pen, or if the bedding material became packed and a large hole developed in the surface. Fresh bedding material was added into the middle of pens or into any hole, and the weight of material added was recorded.

\section{Calf Health Data}

Calf health and cleanliness scores were recorded from $1 \mathrm{~d}$ of age until the weaning date. Calves were observed daily after the morning feeding. The fecal fluidity score developed by Larson et al. (1977) was used, in which 1 = normal fluidity, 2 = spreads slightly, $3=$ moderately spreads, and $4=$ watery (severe scours). When fecal materials were not available for scoring because of mixing with bedding materials, calves were assigned a missing value. When the fluidity score was $>2,4 \mathrm{~mL}$ of ceftiofur hydrochloride (Excenel; Pharmacia \& Upjohn Company, Kalamazoo, MI) was given by intramuscular injection daily until fluidity score was $\leq 2$. Scour days were defined as days when calves had a fluidity score $>2$ and received antibiotic.

Calf cleanliness score was estimated daily by a modification of the Pharmacia Animal Health Hygiene Scorecard (Pharmacia \& Upjohn Co.) for milking dairy cows using a scale of $1=$ calf is clean (not dirty around thighs or body), only manure at lower ends of legs, 2 = tail head region and back of calf are soiled with manure, $3=$ tail head region, thighs or legs are soiled with manure, and $4=$ thighs, legs, and tail head region are soiled with manure.

\section{Blood Samples}

Blood was collected (approximately $4 \mathrm{~h}$ after the morning milk replacer feeding) by jugular venipuncture into plain glass vacuum tubes at $1 \mathrm{~d}$ and at 3 and 6 wk of age. Blood was centrifuged and serum frozen $\left(-20^{\circ} \mathrm{C}\right)$ until analyzed for IgG, cortisol, and $\alpha_{1}$-acid glycoprotein (AGP). Serum concentrations of IgG (VMRD, Pullman, WA) and AGP (Cardiotech Service, Inc., Louisville, KY) were determined by commercially available radial immunodiffusion kits. Cortisol concentrations were determined by ${ }^{125} \mathrm{I}$ radioimmunoassay (Coat-a-Count; Diagnostic Products Corp., Los Angeles, CA).

Blood was also collected in vacuum tubes containing EDTA. Blood smear slides prepared with a rapid 3step staining kit were used to determine white blood cell differential counts (neutrophils, monocytes, lymphocytes, basophils, and eosinophils; Criterion Sciences Richard-Allan, Kalamazoo, MI), and the neutrophil to lymphocyte ratio (N:L) was calculated.

\section{Behavioral Data}

Calf behavior was recorded once weekly by walking through the barn, at a distance from the pen of at least $2.1 \mathrm{~m}$, every $15 \mathrm{~min}$ from $0900 \mathrm{until} 0100 \mathrm{~h}$ the next day (16 h). Behavior was recorded for each of the following activities by a modification of the methods of Chua et al. (2002) and Hunter and Houpt (1989) in which $1=$ lying (calf's body contacted bedding and ground), $2=$ standing (calf was inactive in an upright position), $3=$ eating (calf's head was in plastic feed bucket), $4=$ drinking (calf's head was in plastic water bucket), $5=$ 
self-grooming (calf was licking itself), 6 = investigating environment (calf was moving or jumping around the pen), and 7 = contacting pen (calf was licking sides of the pen and/or eating bedding materials). Percentage time spent in each activity was calculated for each week.

\section{Bedding Samples}

Bedding samples were collected to measure DM and absorbency on $\mathrm{d} 0$, along with $\mathrm{pH}$, gram-negative bacteria counts, and coliform counts on $\mathrm{d} 0$ and at 14-d intervals throughout the study. Samples on d 14, 28, and 42 were collected before reintroducing material from around the pen or adding any new material. Bedding samples were taken with plastic gloves to remove material from 5 subsampling sites in each pen (4 around the perimeter and 1 from the center) using paper cups (Dixie, Fort James, Norwalk, CT). These subsamples from each pen (from 100 to $140 \mathrm{~g}$ of the bedding materials) were composited and placed into sterile plastic bags. Upon arrival at the laboratory, 20 $\mathrm{g}$ of the bedding sample were removed and analyzed for DM by drying in an oven at $100^{\circ} \mathrm{C}$ for $24 \mathrm{~h}$. Then $5 \mathrm{~g}$ (ambient weight) was removed and mixed with 45 $\mathrm{mL}$ of deionized water for $20 \mathrm{~min}$ to analyze $\mathrm{pH}$ with a pH meter (Denver Instrumental Co., Denver, CO), then left for $3 \mathrm{~h}$ to allow absorption of water. After 3 $\mathrm{h}$, excess water was poured from the sample and a wet weight was obtained (Zehner et al., 1986). Absorbency was calculated by the following equation: absorbency = ([wet weight - ambient weight] $\times 100$ )/ambient weight .

Bacterial populations in bedding were evaluated by weighing $10 \mathrm{~g}$ of fresh bedding sample into $90 \mathrm{~mL}$ of sterile PBS at pH 7.2 in sterile stomacher bags, then mixing using a Stomacher model 400 mixer (Seward, London, England) at low speed for $1 \mathrm{~min}$. A serial dilution of $1: 10$ was aspirated with $1 \mathrm{~mL}$ of solution into $9 \mathrm{~mL}$ of sterile PBS per tube. Each dilution starting at $1 \times 10^{3}$ to $1 \times 10^{7}$ was plated in each of 2 duplicate plates on the surface of the medium. MacConkey agar (Remel, Lenexa, KS) was used to identify gram-negative bacteria and coliform. Bacteria were counted after being incubated for $24 \mathrm{~h}$ at $37^{\circ} \mathrm{C}$ and recorded as cfu/ $\mathrm{g}$ of fresh weight. Plates with 30 to 300 colonies were used to calculate cfu/g, and the numbers were converted to logarithms.

Temperature of the bedding surface was measured weekly. Five points of each pen were measured by infrared thermometer (Raynger ST, Santa Cruz, CA) for temperature beginning at $1300 \mathrm{~h}$ and before adding any new bedding material. Temperature and relative humidity, measured weekly with 2 wireless thermohygrometers (RadioShack, Ft. Worth, TX) averaged $29.9^{\circ} \mathrm{C}$ and $48.8 \%$ inside the barn compared with $32.1^{\circ} \mathrm{C}$ and $45.7 \%$ outside the barn.

The concentration of ammonia from the bedding was quantified by dosimeter gas detection tubes that detected a range of 2.5 to $1000 \mathrm{mg} / \mathrm{L}$ (Zefon International, Inc.; St. Petersburg, FL) when calves were 6 wk of age. After the removal of calf, a single gas detection tube was placed in the middle of each pen approximately 10 $\mathrm{cm}$ from the top of bedding materials for a 24 -h period.

\section{Statistical Analyses}

Final body weight, growth, DMI, and feed efficiency data were analyzed as a randomized complete block design by analysis of GLM covariance using initial weight as a covariant (SAS, 1999). Calves were blocked by the week in which they began the study. The DM, absorbency, hardness, and ammonia concentrations data were analyzed using a randomized complete block design. Least-square means were compared with an F-protected $(P<0.05) t$-test. Scour days, cleanliness score, fecal fluidity score, blood data, calf behavior, bedding score, $\mathrm{pH}$, bedding temperature, bacterial counts, and bedding material additions were analyzed with PROC MIXED (SAS, 1999). Analyses of these data used a repeated measures model that included effects of subject (calf), bedding material types, time, and the first-order interaction (bedding material types $\times$ time). A random statement included block and the block $\times$ treatment interaction. Weekly means were calculated and analyzed for BW gain, starter intake, milk replacer intake, scour days, fecal fluidity score, and cleanliness. Significance was declared at $P<0.05$.

\section{RESULTS AND DISCUSSION}

\section{Growth Performance, Feed Intake, and Health Status}

Samples of the commercial medicated milk replacer mixed with Optimil contained 87.9\% DM, 25\% CP, $14.4 \%$ fat, $1.07 \% \mathrm{Ca}$, and $0.86 \% \mathrm{P}$, and the commercial calf starter contained $91.2 \% \mathrm{DM}, 20 \% \mathrm{CP}, 3.6 \%$ fat, $0.98 \% \mathrm{Ca}$, and $0.85 \% \mathrm{P}$.

The average initial and final BW of calves were not different among bedding types (Table 1 ). The DMI varied among bedding types during wk 2 due to differences in starter intake. Calves bedded with wood shavings had lower starter intakes than those bedded with granite fines and rice hulls. The average BW gains for $\mathrm{d} 0$ through 42 on all bedding types was less than normal standards (658 g/d; Davis and Drackley, 1998). Fat concentration of milk replacer was only $14.4 \%$ by analysis, and may explain the low BW gains. Higher fat 
Table 1. Growth performance, weight gain, and feed utilization of calves $(\mathrm{n}=60)$ bedded with 5 different materials.

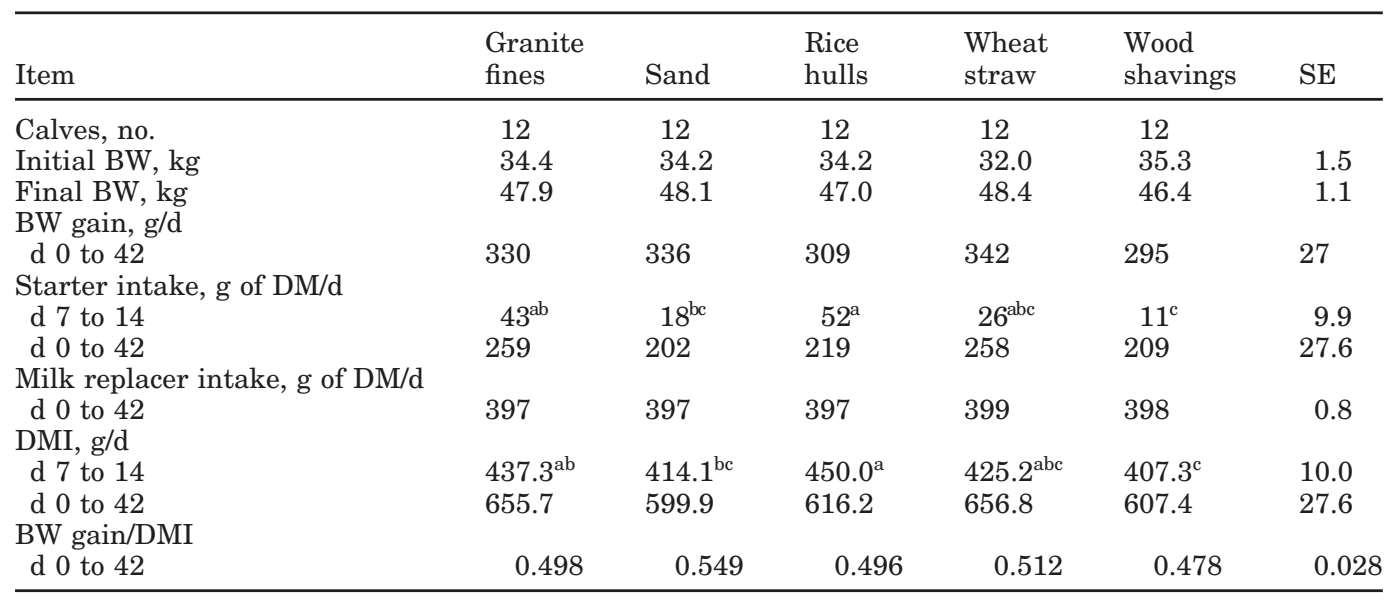

${ }^{\mathrm{a}, \mathrm{b}, \mathrm{c}}$ Means within a row without a common superscript letter $\operatorname{differ}(P<0.05)$.

in milk replacers has improved BW gain (Scibilia et al., 1987).

A treatment by week interaction occurred $(P<0.05)$ with scouring, defined as calves with fecal score $>2$ (Table 2). Calves housed on granite fines had more scour days than those housed on long wheat straw during the first week. During wk 2, calves housed on granite fines and sand had more scour days than calves housed on the other beddings. Scour days were similar during wk 2 for calves bedded on granite fines and sand. Calves bedded on long wheat straw had the lowest number of scour days.

Calves bedded on rice hulls, granite fines, and sand had less desirable $(P<0.05)$ fecal scores than those

Table 2. Scour days, fecal fluidity, and cleanliness scores of calves $(n=60)$ bedded on 5 different materials.

\begin{tabular}{|c|c|c|c|c|c|c|c|}
\hline Item & $\begin{array}{l}\text { Granite } \\
\text { fines }\end{array}$ & Sand & $\begin{array}{l}\text { Rice } \\
\text { hulls }\end{array}$ & $\begin{array}{l}\text { Wheat } \\
\text { straw }\end{array}$ & $\begin{array}{l}\text { Wood } \\
\text { shavings }\end{array}$ & Mean & $\mathrm{SE}$ \\
\hline Calves treated, no. & 12 & 11 & 12 & 5 & 10 & & \\
\hline \multicolumn{6}{|l|}{ Scour days } & & 0.1 \\
\hline d 7 to 14 & $2.6^{\mathrm{a}}$ & $\begin{array}{l}0 . \mathrm{b}^{\mathrm{a}} \\
2.2^{\mathrm{a}}\end{array}$ & $1.5^{\mathrm{b}}$ & $0.4^{\mathrm{de}}$ & $1.0^{\mathrm{bc}}$ & & $\begin{array}{l}0.1 \\
0.1\end{array}$ \\
\hline d 14 to 28 & $0.2^{\mathrm{de}}$ & $0.1^{\mathrm{de}}$ & $0.0^{\mathrm{e}}$ & $0.0^{\mathrm{e}}$ & $0.0^{\mathrm{e}}$ & & 0.1 \\
\hline d 28 to 42 & $0.0^{\mathrm{e}}$ & $0.0^{\mathrm{e}}$ & $0.0^{\mathrm{e}}$ & $0.0^{\mathrm{e}}$ & $0.0^{\mathrm{e}}$ & & 0.1 \\
\hline \multicolumn{8}{|l|}{ Fecal fluidity score ${ }^{1}$} \\
\hline d 0 to 7 & 2.2 & 2.3 & 2.4 & 1.7 & 1.7 & $2.0^{\mathrm{y}}$ & 0.06 \\
\hline d 7 to 14 & 2.5 & 2.5 & 2.4 & 1.8 & 2.1 & $2.3^{\mathrm{z}}$ & 0.06 \\
\hline d 14 to 28 & 1.4 & 1.2 & 1.1 & 1.3 & 1.1 & $1.2^{\mathrm{x}}$ & 0.06 \\
\hline d 28 to 42 & 1.2 & 1.1 & 1.2 & 1.1 & 1.1 & $1.1^{\mathrm{x}}$ & 0.06 \\
\hline Mean & $1.61^{\mathrm{n}}$ & $1.59^{\mathrm{n}}$ & $1.58^{\mathrm{n}}$ & $1.38^{\mathrm{m}}$ & $1.38^{\mathrm{m}}$ & & \\
\hline $\mathrm{SE}$ & 0.057 & 0.057 & 0.057 & 0.057 & 0.057 & & \\
\hline \multicolumn{8}{|l|}{ Cleanliness $^{2}$} \\
\hline d 0 to 7 & 1.3 & 1.1 & 1.1 & 1.0 & 1.1 & $1.1^{\mathrm{x}}$ & 0.1 \\
\hline d 7 to 14 & 2.2 & 1.4 & 1.6 & 1.5 & 1.3 & $1.6^{\mathrm{y}}$ & 0.1 \\
\hline d 14 to 21 & 2.2 & 1.5 & 1.4 & 1.6 & 1.2 & $1.6^{\mathrm{y}}$ & 0.1 \\
\hline d 21 to 28 & 2.2 & 1.5 & 1.5 & 1.6 & 1.3 & $1.6^{\mathrm{y}}$ & 0.1 \\
\hline d 28 to 35 & 2.0 & 1.5 & 1.9 & 1.6 & 1.5 & $1.7^{\mathrm{y}}$ & 0.1 \\
\hline d 35 to 42 & 2.3 & 2.0 & 2.0 & 1.7 & 1.5 & $1.9^{\mathrm{z}}$ & 0.1 \\
\hline Mean & $2.0^{\mathrm{m}}$ & $1.5^{\mathrm{n}}$ & $1.6^{\mathrm{n}}$ & $1.5^{\mathrm{n}}$ & $1.3^{\mathrm{n}}$ & & \\
\hline $\mathrm{SE}$ & 0.14 & 0.14 & 0.14 & 0.14 & 0.14 & & \\
\hline
\end{tabular}

${ }^{1}$ Fecal fluidity score using scale $1=$ normal to 4 = watery.

${ }^{2}$ Cleanliness score using scale 1 = calf is clean (not dirty around thigh or body), only manure at lower ends of legs to $4=$ thigh, legs, and tail head region are soiled with manure.

a,b,c,d,e Means within a category without a common superscript letter differ $(P<0.05)$; bedding by day interaction $(P<0.05)$.

${ }^{\mathrm{m}, \mathrm{n}}$ Means within a row without a common superscript letter differ $(P<0.05)$.

${ }^{\mathrm{x}, \mathrm{y}, \mathrm{z}}$ Means within a column without a common superscript letter $\operatorname{differ}(P<0.05)$. 
Table 3. Blood variables of calves as affected by week $(n=60)$.

\begin{tabular}{llccl}
\hline Time & $\begin{array}{l}\text { Cortisol } \\
(\mu \mathrm{g} / \mathrm{dL})\end{array}$ & $\begin{array}{l}\text { IgG } \\
(\mathrm{mg} / \mathrm{dL})\end{array}$ & $\begin{array}{l}\mathrm{AGP} \\
(\mu \mathrm{g} / \mathrm{mL})\end{array}$ & $\mathrm{N}: \mathrm{L}^{2}$ \\
\hline D 1 & $4.84^{\mathrm{x}}$ & $958^{\mathrm{y}}$ & $1403^{\mathrm{x}}$ & $1.85^{\mathrm{x}}$ \\
Wk 3 & $0.55^{\mathrm{y}}$ & $921^{\mathrm{y}}$ & $613^{\mathrm{y}}$ & $0.38^{\mathrm{y}}$ \\
Wk 6 & $0.45^{\mathrm{y}}$ & $1239^{\mathrm{x}}$ & $343^{\mathrm{z}}$ & $0.37^{\mathrm{y}}$ \\
SE & 0.20 & 74 & 53 & 0.11 \\
\hline
\end{tabular}

$\mathrm{x}, \mathrm{y}, \mathrm{z}$ Means within a column without a common superscript letter differ $(P<0.05)$.

${ }^{1} \mathrm{AGP}=\alpha_{1}$-acid glycoprotein.

${ }^{2} \mathrm{~N}: \mathrm{L}=$ Neutrophil:lymphocyte ratio.

bedded on long wheat straw and wood shavings (Table 2 ). Feces were more visible on granite fines and sand than on the other bedding materials, and that could have affected the fecal score and hence the number of antibiotic treatments. Fecal fluidity score (Table 2) was higher at $2 \mathrm{wk}$ of age than in some previous studies (Quigley and Drew, 2000; Quigley et al., 1995) regardless of bedding types. However, none of the calves died during this trial. Fecal scores were greatest $(P<0.05)$ in wk 2 , and scores in both wk 1 and 2 were greater than scores in wk 3 to 6 (Table 2).

Calf cleanliness scores varied $(P<0.05)$ among bedding materials (Table 2). Calves were dirtiest when granite fines were used. Manure was mixed with or absorbed by rice hulls, long wheat straw, wood shavings, and sand, whereas feces tended to remain on the surface of the granite fines because they were packed after use. The rice hulls tended to adhere to the calves more than other materials. Calves' skin appeared wetter when bedded with sand and had material near the tail area when bedded with long wheat straw compared with calves bedded on other materials. Calf cleanliness scores varied $(P<0.05)$ with time (Table 2 ). Calves were cleanest during wk 1 and were dirtiest during wk 6 . Calf cleanliness scores did not differ during wk 2 to 5 .

\section{Physiological Responses}

Serum IgG concentration was higher $(P<0.05)$ at 6 wk of age than earlier but was not affected by bedding materials (Table 3). The IgG concentration on $\mathrm{d} 1$ of age $(958 \mathrm{mg} / \mathrm{dL})$ was less than the recommended 1000 $\mathrm{mg} / \mathrm{dL}$ (Quigley et al., 2001; Holloway et al., 2002). McGuire and Adams (1982) reported that the adequate level of IgG concentration should be greater than 1600 $\mathrm{mg} / \mathrm{dL}$. This failure of passive transfer may explain the increased fecal scores during wk 2 and the lower than expected BW gains for calves in the study (Quigley et al., 1995). Colostral IgG concentration is an important factor in the calf's acquisition of passive immunity, and the rate of absorption of IgG increases with increasing colostral IgG concentration. Therefore, feeding double the recommended rate of colostrum using an esophageal tube may reduce the rate of failure of passive transfer (Cabell, 2002). Immunoglobulin G has to be present in the gut to protect calves from viral enteritis during the first 2 wk of age (Snodgrass et al., 1982; Castrucci et al., 1984; Saif and Smith, 1985).

Serum cortisol concentration and N:L ratio were stress indices that varied $(P<0.05)$ by week. The cortisol level was highest on $d 1$ and declined on wk 3 and 6 of age (Table 3) as observed previously by Higginbotham and Stull (1997) and Coleman et al. (1996). The $\mathrm{N}$ :L ratio declined from $\mathrm{d} 1$ to wk 3 and did not differ from wk 3 to 6 (Table 3); a similar pattern was reported by Higginbotham and Stull (1997). Friend et al. (1985) reported that $\mathrm{N}: \mathrm{L}$ ratios of calves in pens were 0.37 , almost the same as in this trial.

There were differences $(P<0.05)$ by week for percentages of neutrophils and lymphocytes (data not shown). However, bedding treatment did not affect differential white blood cell counts. As calves' ages increased, the percentage of neutrophils for all bedding types decreased while the percentage of lymphocytes increased. There were no changes in the percentages of monocytes, eosinophils, and basophils due to age or bedding type.

Serum AGP concentration is a marker of disease and inflammation. Its production is stimulated in hepatocytes by the release of cytokines such as interleukin-1, interleukin-6, and tumor necrosis factor- $\alpha$ from macrophages and monocytes. Higginbotham and Stull (1997) and Itoh et al. (1993) reported that average serum AGP concentrations for neonatal calves were 1172 and $1368 \mu \mathrm{g} / \mathrm{mL}$, respectively, levels similar to our results. In those studies AGP gradually decreased to $176 \pm 28 \mu \mathrm{g} / \mathrm{mL}$ (Itoh et al., 1993) and $815 \mu \mathrm{g} / \mathrm{mL}$ (Higginbotham and Stull, 1997) compared with our data, $613 \mu \mathrm{g} / \mathrm{mL}$. Our data also showed that AGP was greatest on $\mathrm{d} 1$ and declined with calf age. Bedding treatments had no effect $(P>0.05)$ on AGP.

\section{Behavioral Data}

The percentage of time for self-grooming of calves was affected by bedding materials. Calves housed on rice hulls (Figure 1) and sand had greater self-grooming behavior than those housed on long wheat straw. Rice hulls adhered to the calves' skin, and this may account for the tendency of these calves to conduct more self-grooming. No differences among bedding materials for calf behavioral traits of standing, eating, drinking, investigating environment, and contacting pen were observed. 


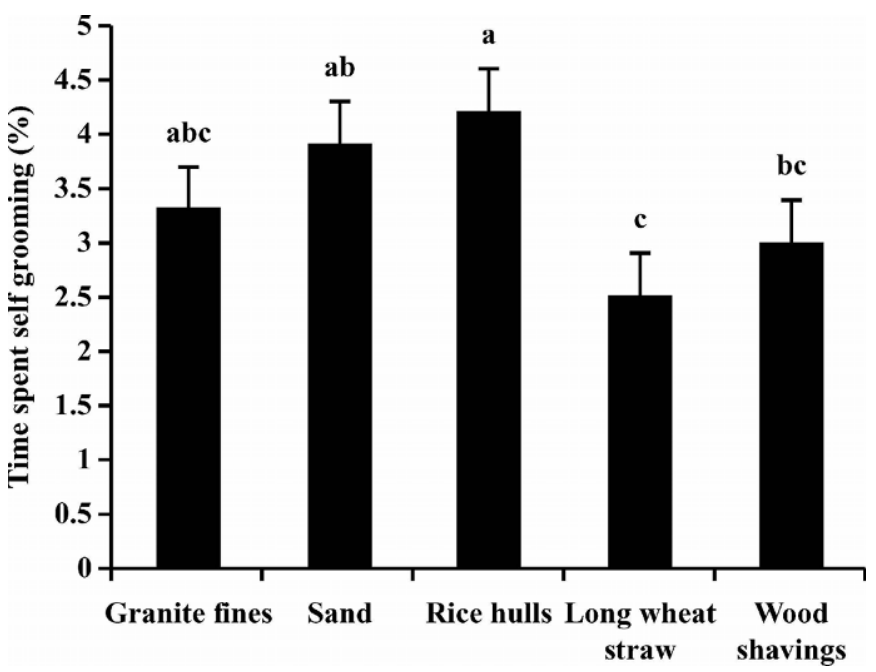

Figure 1. Percentage of time spent self grooming was different because of bedding materials. Bars with different superscripts are different $(P<0.05)$.

Calf behavior and activities including lying, standing, eating, self-grooming, investigating environment, and contacting pen were affected $(P<0.05)$ by age (Table 4). The percentage of time spent lying and standing decreased, while the percentage of time for eating, self-grooming, investigating environment, and contacting pen were increased as calves' age increased $(P<0.05$; Table 4$)$. The percentage of time spent lying, 73.2 to $81 \%$, was similar to the research of Wilson et al. (1999) and Higginbotham and Stull (1997).

\section{Hygiene Quality of Bedding Materials}

Dry matter, absorbency, and hardness of clean bedding materials on $\mathrm{d} 0$ and ammonia concentration on d 42 differed $(P<0.05)$ for bedding types. Dry matter of bedding materials was ranked as sand (100\%) and granite fines $(97.4 \%)$ greater than wood shavings (91\%) and long wheat straw $(90.5 \%)$ and rice hulls (89\%). Long wheat straw was the highest in absorbency $(340.8 \%)$ and was softest $(9.1 \mathrm{~cm})$. Rice hulls and wood shavings had the same absorbency (185\%) and hardness $(2.1 \mathrm{~cm})$, but were more absorbent than sand $(26.5 \%)$ or granite fines $(32.5 \%)$. Long wheat straw, rice hulls, and wood shavings, being organic materials, allowed more absorption of water. Granite fines $(1.5 \mathrm{~cm})$ formed a harder surface than sand $(2.6$ $\mathrm{cm}$ ) because the finer texture of granite fines packed more easily.

On d 42 the concentration $(\mathrm{mg} / \mathrm{kg}$ per hour; $P<0.05)$ of ammonia at $10 \mathrm{~cm}$ above the bedding surface for a 24-h period was 1.1 for long wheat straw, 1.6 for sand, 1.7 for rice hulls and wood shavings, and 1.9 for granite fines $(\mathrm{SE}=0.15)$. The concentrations of ammonia observed had no effect on calf well being. No respiratory diseases were observed. An ammonia threshold limit value of $15 \mathrm{mg} / \mathrm{kg}$ is reported by Seedorf and Hartung (1999). Long wheat straw may have had the lowest ammonia concentration because it had better drainage than other materials (Airaksinen et al., 2001).

Bedding score declined $(P<0.05)$ from 1.1 on $\mathrm{d} 0$ to 2.5 on $\mathrm{d} 42$. Sand (Table 5) was the dirtiest, whereas rice hulls, long wheat straw, and wood shavings stayed cleaner because of the particle size of the bedding materials. Inorganic bedding materials (granite fines and sand) had smaller particle sizes than organic bedding materials (rice hulls, long wheat straw, and wood shavings). Small particles would have a greater chance of mixing bedding and the manure than large particles. Sand, rice hulls, and wood shavings mixed with the manure; granite fines appeared to keep the manure on the surface, possibly because granite fines were packed after calves occupied the pen; long wheat straw more readily covered manure after calves occupied the pen. In addition, the absorbency of organic bedding materials (rice hulls, long wheat straw, and wood shavings) was greater than that of inorganic bedding materials (granite fines and sand).

There was an interaction of bedding material by week of sampling for $\mathrm{pH}$ (Table 5). Before use, the $\mathrm{pH}$ of organic bedding materials (wood shavings < rice hulls < long wheat straw) were lower than that of inorganic ones (sand < granite fines). After use, the

Table 4. Percentage of time spent on different activities as affected by week $(n=60)$.

\begin{tabular}{llllllll}
\hline Week & Lying & Standing & Eating & $\begin{array}{l}\text { Self } \\
\text { grooming }\end{array}$ & $\begin{array}{l}\text { Investigating } \\
\text { environment }\end{array}$ & $\begin{array}{l}\text { Contacting } \\
\text { pen }\end{array}$ & Drinking \\
\hline 1 & $81.0^{\mathrm{w}}$ & $11.4^{\mathrm{w}}$ & $1.4^{\mathrm{z}}$ & $2.6^{\mathrm{y}}$ & $0.2^{\mathrm{y}}$ & $2.7^{\mathrm{z}}$ & 1.0 \\
2 & $75.2^{\mathrm{x}}$ & $9.3^{\mathrm{x}}$ & $3.5^{\mathrm{y}}$ & $2.6^{\mathrm{y}}$ & $0.8^{\mathrm{xy}}$ & $6.9^{\mathrm{y}}$ & 1.6 \\
3 & $74.1^{\mathrm{x}}$ & $6.7^{\mathrm{y}}$ & $4.6^{\mathrm{xy}}$ & $2.9^{\mathrm{xy}}$ & $1.1^{\mathrm{x}}$ & $9.0^{\mathrm{x}}$ & 1.3 \\
4 & $73.3^{\mathrm{x}}$ & $6.0^{\mathrm{yz}}$ & $5.5^{\mathrm{x}}$ & $4.0^{\mathrm{wx}}$ & $2.1^{\mathrm{w}}$ & $8.3^{\mathrm{xy}}$ & 1.2 \\
5 & $75.6^{\mathrm{x}}$ & $6.4^{\mathrm{y}}$ & $4.5^{\mathrm{xy}}$ & $4.0^{\mathrm{w}}$ & $2.8^{\mathrm{w}}$ & $5.8^{\mathrm{y}}$ & 1.0 \\
6 & $73.2^{\mathrm{x}}$ & $4.4^{\mathrm{z}}$ & $4.6^{\mathrm{xy}}$ & $4.4^{\mathrm{w}}$ & $2.9^{\mathrm{w}}$ & $7.2^{\mathrm{xy}}$ & 1.2 \\
$\mathrm{SE}$ & 1.4 & 1.1 & 0.5 & 0.4 & 0.5 & $0.8^{2}$ & 0.3 \\
\hline
\end{tabular}

w,x,y,z Means within a column without a common superscript letter differ $(P<0.05)$. 
Table 5. Physical characteristics of bedding, bacterial count, amount used, and cost of 5 bedding materials.

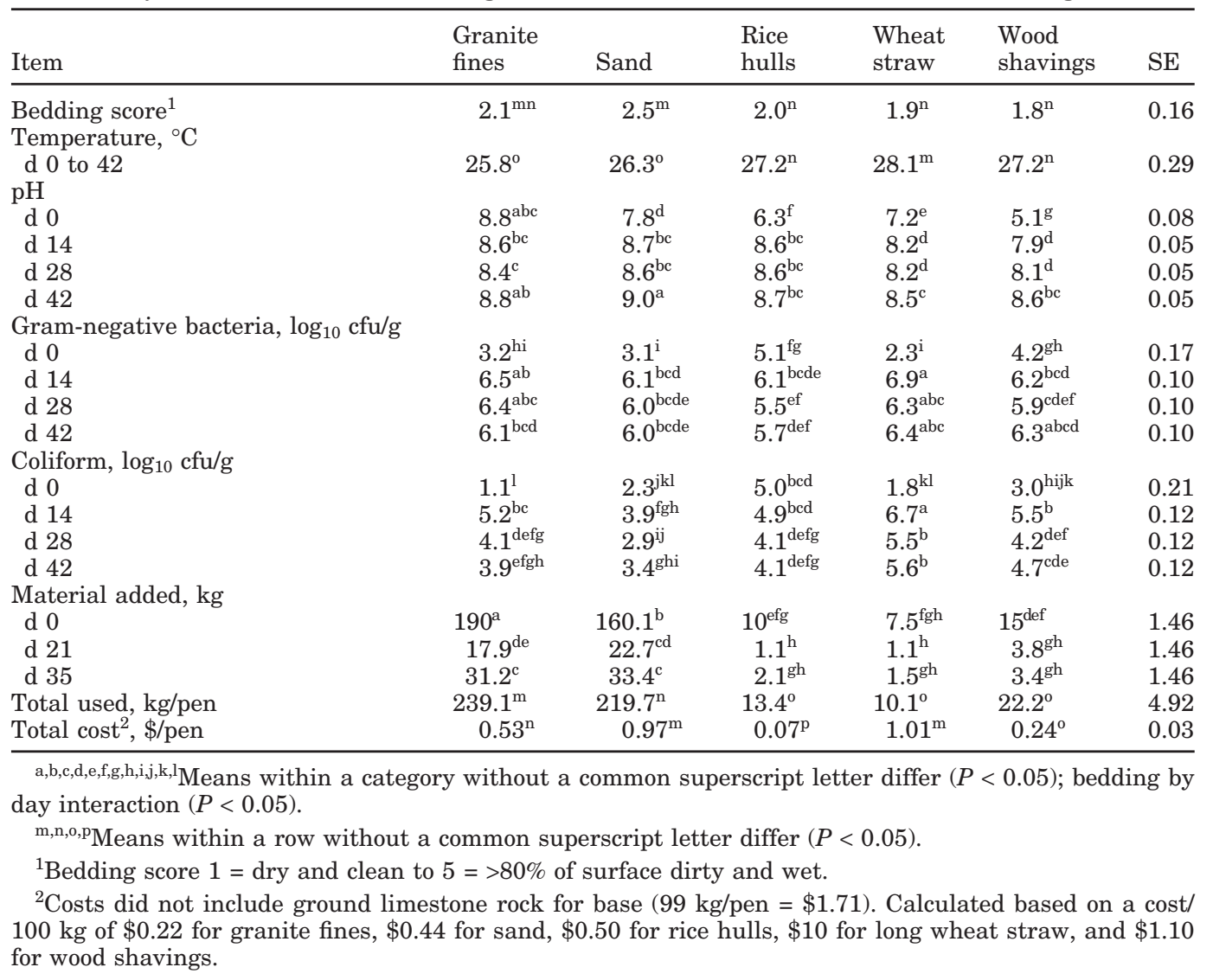

$\mathrm{pH}$ of organic bedding materials and sand increased as time passed. Perhaps this was due to ammonia from urine and the physical properties of the bedding types. The $\mathrm{pH}$ for wood shavings and long wheat straw was similar to that reported by Ward et al. (2001).

Surface temperature was affected by bedding materials and time $(P<0.05$; Table 5$)$. As time passed, temperature of all bedding materials declined from $28.5^{\circ} \mathrm{C}$ on $\mathrm{d} 0$ to $24.4^{\circ} \mathrm{C}$ on $\mathrm{d} 42$, possibly because the bedding materials absorbed urine; in addition, the air temperatures decreased in the final 3 wk of the study. Long wheat straw was warmest, and rice hulls and wood shavings were warmer than granite fines and sand. The surface temperatures and $\mathrm{pH}$ values were usually adequate for gram-negative bacteria and coliform survival (Jay, 2000).

Gram-negative bacteria and coliforms (Table 5) showed different bedding material by week interactions $(P<0.05)$. Before use, gram-negative bacteria counts were ranked: rice hulls and wood shavings greater than granite fines, sand, and long wheat straw. Initial coliform counts were ranked: rice hulls greater than wood shavings, sand, long wheat straw, and granite fines. After calves occupied the pen, gram-negative bacteria counts for all beddings and coliform counts for all beddings except rice hulls increased $(P<0.05)$ on d 14. Gram-negative bacteria counts on d 28 and 42 did not differ from d 14 for any bedding materials. Coliform counts on d 14 for all bedding except rice hulls were higher than those on d 28 and 42 . On d 42 , long wheat straw had the highest coliform counts. Long wheat straw had greater amino acids, no inhibitory substrates (Bey et al., 2002), lower C:N ratio (Ward et al., 2000), and higher absorbency for bacteria growth compared with wood shavings.

\section{Cost of Bedding Material Types}

Weight of materials used per pen (Table 5) was greatest for granite fines, followed by sand, with rice hulls, long wheat straw, and wood shavings requiring the least material. Using the retail price, the cost of bedding materials per pen from d 0 through 42 were calculated. Long wheat straw (\$1.01) and sand (\$0.97) were the most expensive. The cost for granite fines (\$0.53) was greater than that for wood shavings $(\$ 0.24)$, with rice hulls $(\$ 0.07)$ being the least expensive. However, regional availability and the required 
transportation distance for each material will significantly affect the on-farm price.

\section{CONCLUSIONS}

Growth rate and feed efficiency of calves from $d 1$ to 42 were not affected $(P>0.05)$ by 5 different bedding materials. Dry matter intake differed $(P<0.05)$ in wk 2 and was lowest for calves bedded with wood shavings. In addition, the number of days calves were treated with antibiotics due to scours was affected $(P<0.05)$ by bedding materials during the first $2 \mathrm{wk}$, with calves on sand and granite fines having the higher rate of treatment. Bedding materials had no effect on serum IgG concentration, stress indices (cortisol and N:L ratio), and AGP. These blood variables were influenced by week. Calf behavior and activities except time spent drinking were affected by week $(P<0.05)$. Bedding types affected $(P<0.05)$ self-grooming only. Overall, the results of this study suggested that the performance of heifer calves, regardless of bedding materials used during the preweaning stage, were similar. This study was conducted in the late summer and fall, during a period of moderate temperatures. Differences in calf performance due to bedding material may occur in colder environmental temperatures, and this possibility warrants further investigation.

\section{ACKNOWLEDGMENTS}

The authors gratefully acknowledge the contributions of the Ark-Tenn Dairy Research and Development Facility, Center Ridge, for use of their calves and facilities and very much appreciate the assistance of Jerold Brock, Larry Anglea, and their employees. The authors thank Ferrell Gray, Donna Fill Granite Fines, Little Rock, AR, for providing material for this study. The authors also thank Troy Wistuba, Hernando Florez-Diaz, Ester Flores, Maria Mashingo, Doug Galloway, Robin Ogden, Karen Anschutz, Kathleen McElyea, and Thaneth Srikumlaithong of the University of Arkansas for assistance in fieldwork and laboratory analyses.

\section{REFERENCES}

Airaksinen, S., H. Heinonen-Tanski, and M.-L. Heiskanen. 2001. Quality of different bedding materials and their influence on the compostability of horse manure. J. Equine Vet. Sci. 21:125-130.

Association of Official Analytical Chemists. 1990. Official Methods of Analysis. 15th ed. AOAC, Washington, DC.

Bey, R. F., J. K. Reneau, and R. J. Farnsworth. 2002. The role of bedding management in udder health. Page 45-55 in Natl. Mastitis Counc. Annu. Mtg. Proc., Washington, DC.

Cabell, E. 2002. Colostrum, intestinal IgG and calf diarrhoea. Br. Cattle Vet. Assoc. 10:137-141.

Castrucci, G., F. Frigeri, M. Ferrari, V. Cilli, F. Caleffi, V. Aldrovandi, and A. Nigrelli. 1984. The efficacy of colostrum from cows vaccinated with rotavirus in protecting calves to experimentally induced rotavirus infection. Comp. Immunol. Microbiol. Infect. Dis. 7:11-18.

Chua, B., E. Coenen, J. van Delen, and D. M. Weary. 2002. Effects of pair versus individual housing on the behavior and performance of dairy calves. J. Dairy Sci. 85:360-364.

Coleman, D. A., B. R. Moss, and T. A. McCaskey. 1996. Supplemental shade for dairy calves reared in commercial calf hutches in a Southern climate. J. Dairy Sci. 79:2038-2043.

Davis, C. L., and J. K. Drackley. 1998. Starter feed: Importance, composition, and intake. Pages 283-302 in The Development, Nutrition, and Management of the Young Calf. Iowa State Univ. Press, Ames, IA.

Fraser, D. 1985. Selection of bedded and unbedded areas by pigs in relation to environmental temperature and behaviour. Appl. Anim. Behav. Sci. 14:117-126.

Friend, T. H., G. R. Dellmeier, and E. E. Gbur. 1985. Comparison of four methods of calf confinement. I. Physiology. J. Anim. Sci. 60:1095-1101.

Higginbotham, G. E., and C. L. Stull. 1997. Performance and health of dairy calves using different types of commercial housing. Prof. Anim. Sci. 13:18-23.

Hogan, J. S., K. L. Smith, K. H. Hoblet, D. A. Todhunter, P. S. Schoenberger, W. D. Hueston, D. E. Pritchard, G. L. Bowman, L. E. Heider, B. L. Brockett, and H. R. Conrad. 1989. Bacterial counts in bedding materials used on nine commercial dairies. J. Dairy Sci. 72:250-258.

Holloway, N. M., J. W. Tyler, J. Lakritz, S. L. Carlson, R. K. Tessman, and J. Holle. 2002. Serum immunoglobulin G concentrations in calves fed fresh colostrum or a colostrum supplement. J. Vet. Intern. Med. 16:187-191.

Hunter, L., and K. A. Houpt. 1989. Bedding material preferences of ponies. J. Anim. Sci. 67:1986-1991.

Itoh, H., K. Tamura, M. Izumi, Y. Motoi, and Y. Funnayama. 1993. Characterization of serum $\mathrm{a}_{1}$-acid glycoprotein in fetal and newborn calves during development. Am. J. Vet. Res. 54:591-595.

Jay, J. M. 2000. Intrinsic and extrinsic parameters of food that effect microbial growth. Pages 35-56 in Modern Food Microbiology. 6th ed. Aspen Publishing, Inc., Gaithersburg, MD.

Larson, L. L., F. G. Owen, J. L. Albright, R. D. Applemen, R. C. Lamb, and L. D. Muller. 1977. Guidelines toward more uniformity in measuring and reporting calf experimental data. J. Dairy Sci. 60:989-991.

McGuire, T. C., and D. S. Adams. 1982. Failure of colostral immunoglobulin transfer to calves: Prevalence and diagnosis. Comp. Cont. Educ. 4:35.

Norheim, K., and E. Simensen. 1985. An epidemiological study of factors affecting serum IgG levels in dairy calves. Nord. Vet. Med. 37:121-135.

Quigley, J. D., III, and M. D. Drew. 2000. Effects of oral antibiotics or bovine plasma on survival, health and growth in dairy calves challenged with Escherichia coli. Food Agric. Immunol. 12:311-318.

Quigley, J. D., III, K. R. Martin, D. A. Bemis, L. N. D. Potgieter, C. R. Reinemeyer, B. W. Rohrbach, H. H. Dowlen, and K. C. Lamar. 1995. Effects of housing and colostrum feeding on serum immunoglobulins, growth, and fecal scores of Jersey calves. J. Dairy Sci. 78:893-901.

Quigley, J. D., III, R. E. Strohbehn, C. J. Kost, and M. M. O'Brien. 2001. Formulation of colostrum supplements, colostrum replacers and acquisition of passive immunity in neonatal calves. J. Dairy Sci. 84:2059-2065.

Saif, L. J., and K. L. Smith. 1985. Enteric viral infections of calves and passive immunity. J. Dairy Sci. 68:206-228.

SAS User's Guide: Statistics, Version 8 Edition. 1999. SAS Inst., Inc., Cary, NC.

Scibilia, L. S., L. D. Muller, R. S. Kensinger, T. F. Sweeney, and P. R. Shellenberger. 1987. Effect of environmental temperature and dietary fat on growth and physiological responses of newborn calves. J. Dairy Sci. 70:1426-1433.

Seedorf, J., and J. Hartung. 1999. Survey of ammonia concentrations in livestock buildings. J. Agric. Sci. 133:433-437. 
Snodgrass, D. R., J. Stewart, J. Taylor, F. L. Krautil, and M. L. Smith. 1982. Diarrhoea in dairy calves reduced by feeding colostrum from cows vaccinated with rotavirus. Res. Vet. Sci. 32:70-73.

Thoreson, D. R., D. C. Lay, L. L. Timms, and L. R. Rolling. 2000. Dairy free stall preference field study. 2000 Dairy Report - Iowa State University.

Tucker, C. B., D. M. Weary, and D. Fraser. 2003. Effects of three types of free-stall surfaces on preferences and stall usage by dairy cows. J. Dairy Sci. 86:521-529.

Ward, P. L., J. E. Wohlt, and S. E. Katz. 2001. Chemical, physical, and environmental properties of pelleted newspaper compared to wheat straw and wood shavings as bedding for horses. J. Anim. Sci. 79:1359-1369.

Ward, P. L., J. E. Wohlt, P. K. Zajac, and K. R. Cooper. 2000. Chemical and physical properties of processed newspaper compared to wheat straw and wood shavings as animal bedding. J. Dairy Sci. 83:359-367.

Wilson, L. L., T. L. Terosky, C. L. Stull, and W. R. Stricklin. 1999 Effects of individual housing design and size on behavior and stress indicators of special-fed Holstein veal calves. J. Anim. Sci. 77:1341-1347.

Zehner, M. M., R. J. Farnsworth, R. D. Appleman, K. Larntz, and J. A. Springer. 1986. Growth of environmental mastitis pathogens in various bedding materials. J. Dairy Sci. 69:1932-1941. 